\title{
HAPTOGLOBIN CONCENTRATIONS IN BLOOD OF DAIRY COWS WITH INFLAMMATORY DISEASES
}

\author{
P. Mudron̆ \\ pavol.mudron@uvlf.sk
}

University of Veterinary Medicine and Pharmacy in Košice, Clinic of ruminants, Komenského 73, Košice 04181, Slovakia

Haptoglobin is an acute phase protein produced primarily in the liver in response to pro-inflammatory cytokines. The objective of this field study was to determine if common inflammatory diseases like mastitis and claw inflammatory disorders are associated with increased serum haptoglobin. Moreover, the sensitivity and specificity of haptoglobin levels were tested. 237 Holstein dairy cows were included in the study; farm feeding management was based on TMR and the dairy cows were housed in free stalls with cubicles. Health condition of mammary gland and claws was examined in the crush. The subclinical mastitis was diagnosed by using California mastitis test. Blood samples were obtained from the jugular vein at the time of the clinical examination and treatment. Serum haptoglobin concentration was measured by colorimetric assay (Tridelta Development, Ireland). Statistical analysis was done by two-way ANOVA. The threshold level of haptoglobin for calculation of sensitivity and specificity was $0.05 \mathrm{~g} / \mathrm{L}$. Clinical mastitis, subclinical mastitis, and inflammatory claw disorders, including digital dermatitis, interdigital dermatitis, pododermatitis, interdigital hyperplasia, and subclinical laminitis were found in 204 dairy cows (INFLA). 33 dairy cows were found to be free of inflammatory changes (CONTROL). Cows with inflammation had higherserum haptoglobin than controls: INFLA - $0.21 \mathrm{~g} / \mathrm{L}$; CONTROL $-0.06 \mathrm{~g} / \mathrm{L}(P<0.01)$. The sensitivity detecting dairy cows with inflammatory disorders by serum haptoglobin levels was $84 \%$, whereas the specificity in the control group of 33 clinically unsuspicious cows was $68 \%$. Results of the study show that the inflammatory disorders in dairy cows are associated with increased concentrations of the serum haptoglobin. However, sensitivity and specificity of the serum haptoglobin are rather low for detection of inflammatory processes in dairy cows.

Keywords: DAIRY COWS, HAPTOGLOBIN, MASTITIS, CLAW INFLAMATION

\section{КОНЦЕНТРАЦІЯ ГАПТОГЛОБІНУ В КРОВІ МОЛОЧНИХ КОРІВ ІЗ ЗАПАЛЬНИМИ ЗАХВОРЮВАННЯМИ}

\author{
П. Мудрон \\ pavol.mudron@uvlf.sk
}

Університет ветеринарної медицини та фармації в Кошице, клініка жуйних тварин, вул. Коменського, 73, м. Кошице, 04181, Словаччина

Гаптоглобін - протеїн гострої фази, який синтезується печінкою за дї прозапальних цитокінів. Метою иього дослідження було встановити, чи супроводжуються такі поширені захворювання, як мастит та запальні порушення ратищь, підвищенням сироваткового гаптоглобіну. Крім того, досліджували чутливість та специфічність встановлення концентрації гаптоглобіну для діагностики цих захворювань. У досліді використано 237 молочних корів голитинської породи, утримання безприв'язне стійлове, годівля - повнораиіонна кормова суміш (TMR). Для оиінки стану молочної залози і ратиць корів фіксували у станку. Субклінічний мастит діагностували за допомогою каліфорнійського маститного тесту (СМТ). Зразки крові брали з яремної вени під час клінічного обстежеення та лікування. Концентраиію гаптоглобіну в сироватиі крові визначали колориметрично (Tridelta Development, Iрландія). Для статистичної обробки результатів використовували двофакторний дисперсійний аналіз ANOVA. Пороговий рівень гаптоглобіну для розрахунку чутливості та специфічності становив 0,05 г/л. Клінічний мастит, субклінічний мастит та запальні захворювання ратиць, зокрема пальцевий дерматит, міжпальцевий дерматит, пододерматит, міжпальцеву гіперплазію та субклінічний ламініт, були виявлені у 204 корів (INFLA). Виявлено, що 33 молочні корови не мають запальних змін (контроль). Корови із запаленням мали вищий вміст гаптоглобіну у сироватиі крові, ніж контрольні: хворі - 0,21 г/л; здорові - 0,06 г/л $(P<0,01)$. Чутливість виявлення запальних процесів у корів за рівнем у сироватці крові гаптоглобіну крові становила $84 \%$, спещифічність методу у групі клінічно здорових корів була $68 \%$. Результати дослідження свідчать, що запальні порушення у молочних корів супроводжуються підвищенням конщентращії 
гаптоглобіну в сироватиі крові. Однак чутливість та специчрічність сироваткового гаптоглобіну надто низькі для діагностики запальних процесів у молочних корів.

\title{
КЛючові слова: МОЛОЧНІ КОРОВИ, ГАПТОГЛОБІН, МАСТИТ, ЗАПАЛЕННЯ РАТИЦЬ
}

\section{КОНЦЕНТРАЦИЯ ГАПТОГЛОБИНА У МОЛОЧНЫХ КОРОВ С ВОСПАЛИТЕЛЬНЫМИ ЗАБОЛЕВАНИЯМИ}

\author{
П. Мудрон \\ pavol.mudron@uvlf.sk
}

Университет ветеринарной медицины и фармации в Кошице, клиника жвачных животных, ул. Коменского, 73, г. Кошице, 04181, Словакия

Гаптоглобин - протеин острой фазы, который синтезируется печенью при действии провоспалительных иитокинов. Целью этого исследования было установить, сопровождаются ли такие распространенные заболевания, как мастит и воспалительные нарушения копьт, повытением сывороточного гаптоглобина. Кроме того, исследовали чувствительность и специфичность установления концентрачии гаптоглобина для диагностики этих заболеваний. В опыте использовано 237 молочных коров голитинской породы, содержсание беспривязное стойловое, кормление - полнорационная кормовая смесь (ПКС). Для оценки состояния молочной железы и копыт коров фиксировали в станке. Субклинический мастит диагностировали с помощью калифорнийского теста на мастит (СМТ). Образиьь крови брали из яремной вены во время клинического обследования и лечения. Конщентрацию гаптоглобина в сыворотке крови определяли колориметрически (Tridelta Development, Ирландия). Для статистической обработки результатов использовали двухфакторньй дисперсионный анализ ANOVA. Пороговый уровень гаптоглобина для расчета чувствительности и специфичности составлял 0,05 г/л. Клинический мастит, субклинический мастит и воспалительные заболевания копыт, в частности пальцевый дерматит, межпальцевый дерматит, пододерматит, межпальцевая гиперплазия и субклинический ламинит, были обнаружены в 204 коров (INFLA). Выявлено, что 33 молочные коровы не имеют воспалительных изменений (контроль). Коровы с воспалением имели высшее содержание гаптоглобина в сыворотке крови, чем контрольные: больные - 0,21, здоровые - 0,06 г/л $(P<0,01)$. Чувствительность выявления воспалительных процессов у коров по уровню в сыворотке крови гаптоглобина составляла 84 \%, специфичность метода в группе клинически здоровых коров была $68 \%$. Результаты исследования свидетельствуют, что воспалительные нарушения в молочных коров сопровождаются повышением концентрации гаптоглобина в сыворотке крови. Однако, чувствительность и специфичность сывороточного гаптоглобина слишком низкие для диагностики воспалительных прочессов у молочных коров.

Ключевые слова: МОЛОЧНЫЕ КОРОВЫ, ГАПТОГЛОБИН, МАСТИТ, ВОСПАЛЕНИЕ КОПЫТ

Haptoglobin is an acute phase protein synthesized in the liver in response to inflammation [3] and it can be measured in serum. The association between infections and elevated serum haptoglobin concentrations was well studied in cows with uterine infection [1,7], mastitis [8] and claw inflammations [11]. Because haptoglobin is an indicator of nonspecific innate immune response activated by various inflammatory lesions, different variables can influence haptoglobin concentrations [2]. Fatty liver can be also associated with increased haptoglobin concentrations [12] and one conclusion is that increased concentrations of haptoglobin around parturition could be caused by negative energy balance [3].
Therefore, the objective of this study was to determine if common inflammatory diseases like mastitis and claw inflammatory disorders are associated with increased blood haptoglobin and to calculate the sensitivity and specifity of haptoglobin measurement.

\section{Materials and methods}

237 Holstein dairy cows were included in the study; farm feeding management was based on TMR and the dairy cows were housed in free stalls with cubicles. Health condition of mammary gland and claws were examined in the crush. The subclinical mastitis was diagnosed by using 
California mastitis test. Blood samples were obtained from the jugular vein at the time of the clinical examination and treatment. Serum haptoglobin concentration was measured by colorimetric assay (Tridelta Development, Ireland). Statistical analysis was done by two way ANOVA. The threshold level of haptoglobin for calculation of sensitivity and specificity was $0.05 \mathrm{~g} / \mathrm{L}$.

\section{Results and discussion}

Clinical mastitis, subclinical mastitis, and inflammatory claw disorders, including digital dermatitis, interdigital dermatitis, pododermatitis, interdigital hyperplasia, and subclinical laminitis were found in 204 dairy cows (INFLA). 33 dairy cows were found to be free of inflammatory processes. Cows with inflammation had higher serum haptoglobin $(0.21 \mathrm{~g} / \mathrm{L})$ than those without inflammation $(0.06 \mathrm{~g} / \mathrm{L})$, respectively $(\mathrm{P}<0.01)$.

The sensitivity detecting dairy cows with inflammatory disorders and claw inflammation by serum haptoglobin levels was $84 \%$ and $90 \%$, respectively. The specificity in the control group of 33 clinically unsuspicious cows was $68 \%$ (table).

In numerous studies it was found that the serum haptoglobin increased in infectious and inflammatory processes such as mastitis, metritis, pyometra, traumatic reticulitis and bacterial infections [10]. The haptoglobin can react very strongly in an acute inflammation and 20-1000 fold increase can be then measured in serum [6].

Table

Serum haptoglobin $(\mathrm{g} / \mathrm{L})$ in dairy cows with claw inflammation and mastitis $(\mathrm{n}=\mathbf{2 3 7})$

\begin{tabular}{|l|c|c|c|c|c|c|}
\hline & Healthy & Inflammation & Claw inflammation & Mastitis & Clinical mastitis & ANOVA \\
\hline Number & 33 & 204 & 26 & 43 & 10 & \\
\hline Haptoglobin & $0.06 \pm 0.04^{\mathrm{a}}$ & $0.21 \pm 0.27^{\mathrm{bc}}$ & $0.35 \pm 0.43^{\mathrm{b}}$ & $0.11 \pm 0.11^{\mathrm{ac}}$ & $0.19 \pm 0.23^{\mathrm{abc}}$ & $\mathrm{P}<0.01$ \\
\hline Sensitivity & & $86 \%$ & $90 \%$ & & & \\
\hline Specifity & $68 \%$ & & & & & \\
\hline
\end{tabular}

A significantly higher serum concentrations of haptoglobin and amyloid alpha were found in dairy cows with clinical mastitis compared to healthy ones [4]. Dairy cows with claw inflammation had usually higher serum haptoglobin levels than healthy cows. Several studies demonstrated that the painful claw inflammations were mostly associated with elevated serum haptoglobin $[5,9]$.

The recent study demonstrated that metabolic stress, indicated as subclinical ketosis as well as calving disorders and RFM in multiparous cows, is associated with haptoglobin concentration, thus, reduced sensitivity and specificity in the detection of inflammations can be expected for haptoglobin measurements during the first week after calving [7].

\section{Conclusion}

Results of the present study show that the inflammatory disorders in dairy cows are associated with increased concentrations of the serum haptoglobin. However, sensitivity and specificity of the serum haptoglobin are rather low for de- tection of inflammatory processes in dairy cows. Therefore, a use of serum haptoglobin for monitoring of inflammatory diseases on the dairy farm level can be recommended only with limitation.

1. Burfeind O.,Sannmann I.,Voigtsberger R., Heuwieser W. Receiver operating characteristic curve analysis to determine the diagnostic performance of serum haptoglobin concentration for the diagnosis of acute puerperal metritis in dairy cows. Animal Reproduction Science, 2014, vol. 149, issue 3-4, pp. 145-151. DOI: 10.1016/j.anireprosci.2014.07.020.

2. Ceciliani F., Ceron J. J., Eckersall P. D., Sauerwein $\mathrm{H}$. Acute phase proteins in ruminants. Journal of Proteomics, 2012, vol. 75, issue 14, pp. 42074231. DOI: 10.1016/j.jprot.2012.04.004.

3. Crawford R. G., Leslie K. E., Bagg R., Paul Dick C., Duffield T. F. The impact of controlled release capsules of monensin on postcalving haptoglobin concentrations in dairy cattle. Canadian Journal of Veterinary Research, 2005, vol. 69, issue 3, pp. 208-214.

4. Eckersall P. D., Young F. J., McComb C., Hogarth C. J., Safi S., Fitzpatrick J. L., Nolan A. M., Weber A., McDonald T. Acute phase proteins in serum and milk from dairy cows with clinical mastitis. Veterinary Record, 2001, vol. 148, issue 2, pp. 35-41. DOI: 10.1136/vr.148.2.35.

5. Jawor P., Steiner S., Stefaniak T., Baumgartner W., Rzasa A. Determination of selected acute phase 
proteins during the treatment of limb diseases in dairy cows. Veterinárni Medicína, 2008, vol. 53, pp. 173-183. DOI: 10.17221/1920-VETMED.

6. Kushner I., Gewurz H., Benson M. D. C-reactives protein and the acute phase response. Journal of Laboratory Clinical Medicine, 1981, vol. 97, issue 6, 739-749.

7. Pohl A., Burfeind O., Heuwieser W. The associations between postpartum serum haptoglobin concentration and metabolic status, calving difficulties, retained fetal membranes, and metritis. Journal of Dairy Science, 2015, vol. 98, issue 7, pp. 4544-4551. DOI: 10.3168/jds.2014-9181.

8. Rezamand P., Hoagland T. A., Moyes K. M., Silbart L. K., Andrew S. M. Energy status, lipid-soluble vitamins, and acute phase proteins in periparturient Holstein and Jersey dairy cows with or without subclinical mastitis. Journal of Dairy Science, 2007, vol. 90, issue 11, pp. 5097-5107. DOI: $10.3168 /$ jds.2007-0035.
9. Smith B. I., Kauffold J., Sherman L. Serum haptoglobin concentrations in dairy cattle with lamenesss due to claw disorders. Veterinary Journal, 2010, vol. 186, issue 2, pp. 162-165. DOI: 10.1016/j.tvj1.2009.08.012.

10. Tóthová Cs., Nagy O., Kováč G. Acute phase proteins and their use in the diagnosis of diseases in ruminants: a review. Veterinární Medicina, 2014, vol. 59, pp. 163-180. DOI: 10.17221/7478-VETMED.

11.Tóthová Cs., Nagy O., Seidel H., Paulíková I., Kováč G. The influence of hoof diseases on the concentrations of some acute phase proteins and other variables of the protein profile in heifers. Acta Veterinaria (Beograd), 2011, vol. 61, issue 2-3, pp. 141-150. DOI: 10.2298/AVB1103141T.

12.Uchida E., Katoh N.,Takahashi K. Induction of serum haptoglobin by administration of ethionine to cows. Journal of Veterinary Medicine and Science, 1993, vol. 55, issue 3, pp. 501-502. DOI: 10.1292/jvms.55.501. 